\title{
Let your kingdom come
}

\author{
L.F. Schulze \\ School for Ecclesiastical Sciences \\ Potchefstroom University for CHE \\ POTCHEFSTROOM
}

\begin{abstract}
Let your kingdom come

As an introduction to the general theme "The kingdom of God", this article presents an overview of the second petition of the Lord's Prayer. This is done under the following headings: the setting, the aspects, and the guidelines of the petition.

The setting shows the very close relation among the first three petitions as pertaining to God's cause, and the priority which his kingship should have in our prayers. In turning to God in our prayers, we turn away from ourselves. Thus prayer is part of our sanctification.

The aspects treated in this article are, firstly, that the second petition is a prayer, implying our helplessness and destitution; secondly, that it concerns God's kingdom, not ours, thereby undercutting every form of modernism, Social Gospel, political theology, and progressive ethical 'goodness' of man; thirdly, it is a petition that the kingdom may come, which happens mysteriously, in God's time, in our history, and according to Scriptures.

In the guidelines it is argued that, in order to live responsibly as Christians, we must know our time, ourselves, and the immutable nature of prophecy.
\end{abstract}

\section{Introduction}

In this article it is attempted to present only some concise and simple remarks about the second petition of the most well-known prayer in Christianity. This is done under the following headings: the setting, the aspects, and the guidelines of the petition. 


\section{The setting}

The first three petitions are inextricably bound together and lead us in our prayer to the absolute predominance of God, of his glory, and of his rule. We, with our supposed pressing needs, our overruling interests, and our high ideals, unexpectedly find ourselves removed to a secondary place, for God's kingdom comes first, above all else, and overshadows our aims and needs (Matt. 6:31-33).

This radical theocentric perspective of Scripture overturns the current Western conception of God as essentially the helper of man in his pressing psychological, social and political needs. Revelation in nature and Scripture indicates not man, but God as the focal point of our attention. The revelation in nature is often forgotten or bypassed. But the "language of creation" (e.g. Ps. 8; Ps. 104; Rom. 1:19-21) confronts all nations and is reflected in their various notions and feelings of a mysterium tremendum. The famous Roman poet Vergil, for instance, sensed the numinous (Postma, 1914). Even atheistic educated natural scientists of the former USSR did speak of a "cosmic intelligence". It is ironic that the church - who should know God more clearly - is the community in which this general awe, this fear of God is eroded by degrading him to a human helper.

The pre-eminence of God, proclaimed by nature, is more clearly revealed in Scripture (Conf. Belg. Art. II). Taught by Scripture, the church should look unto him and in prayer turn wholly to him, yearning for the hallowing if his Name, the coming of his rule, and the obedience to his will. The first three petitions reflect, like the sides of a precious stone, the glorious light of his holiness, the truth of his pre-eminence, and the irrefutability of his sovereignty. He is indeed the sovereign king over the cosmos. The prayer that his kingdom may come does not imply that he is not yet king; neither does it mean that we should "make him king". In fact, sinful man does not acknowledge his kingship any more. Therefore, the second petition is a prayer that God should publicly restore the acknowledgement of his royal right (Grosheide, 1953:25-26).

The petition for the coming of the kingdom is addressed to "Our Father" in heaven. The address reveals the messianic character of the kingdom, for it is only through Christ that we have access to the Father. By his atoning death He tore the curtain of the temple from top to bottom (Matt. 27:51), opening the way to the inner sanctuary where no man dared to stand but where we now can enter with confidence because we participate in Christ (Heb. 3:14). 
To turn wholly to God in prayer is simultaneously a turning away from ourselves. It involves self-denial in order to accept his rule, confession of sins and of God alone as our refuge - a point on which Calvin dwells by saying, inter alia:

This petition, therefore, is duly presented only by those who begin with themselves; in other words, who pray that they may be purified from all the corruptions which disturb the tranquility and impair the purity of God's kingdom (Inst. 3.20.42).

To have a burning zeal for God's cause is part of our sanctification.

Various aspects of the second petition merit closer attention.

\section{The aspects}

\subsection{A prayer}

To pray for the coming of the kingdom does not only presuppose the abnegation of our will but also imply our helplesness. In this context God is indeed a helper, but $\mathrm{He}$ is at the same time much more than a helper $\mathrm{He}$ is a sovereign king. As father and as helper $\mathrm{He}$ is the refuge of his covenant people to whom they can appeal and whose protection they must seek (Ps. 46:1). As sovereign king he is the strong One, the omnipotent creator and sustainer of the universe, the only, incomparable God who shares his power and glory with no one (Is. 40-41).

The relation between knowledge of God and self-knowledge by means of which Calvin introduced us to his Institutes, finds a particular intimate and poised expression in prayer. Our deepening knowledge of him as our father and king is simultaneously reflected in the growing knowledge of our helplessness and destitution. True prayer is always an expression of humility.

\subsection{God's kingdom}

We pray for the coming of God's kingdom. It is not our kingdom, brought about by our zeal. The Social Gospel and its offspring have misread this petition as promoting our social progress and well-being.

Douglas et al. (1989:353) give a succinct description of Social Gospel as:

The attempt to apply the principles of Christianity to the complex society produced by industrialization and capitalism in the U.S. between 1890 and 1940. A prominent theological idea was that of the kingdom of God, which was interpreted in terms of a just and free human society in the present age. 
One could perhaps try to look behind the door of Social Gospel, hoping to find a "realised eschatology". Instead, one finds three other figures there. The first is A. Ritschl who emphasised the totally immanent character of the kingdom, belonging to the present world, and which can be developed by human ethical impulses ( Nauta, 1961; Ridderbos, 1972:6). Behind Ritschl, and inspiring him, is a second figure - the common late 19th century's belief in history as progress (Van Niftrik, 1966:11-12; 42-51; Ward, 1998:xix). Social Gospel failed as a movement for two reasons: its neglect of the effects of sin, and a revivalist reaction against it. Yet Social Gospel's essential aim of transforming society was kept alive and gradually re-formed by endemic American pragmatism into the luxurious figure of feminist theology. Pragmatism is the third figure behind the door. Rebecca Chopp shows American feminist theology to be embedded in pragmatism. She coins the term public theology (to which feminist theology belongs) as "the theological counterpart to pragmatism" (Chopp, 1998:238), and writes:

American public theology begins not in distinguishing Christian tradition from common human experience, but in the movement of Christian practice speaking to the problems, doubts, and desires within the American situation (Chopp, 1998:239).

Thus the immanent Ritschlean pie is now dished up with political gravy. What remains of theology in this dish is mostly contained in the jargon.

Meanwhile, "political" theology is not restricted to feminism. It spread its wings also in liberation theology, about which much has been written, and which is only mentioned here in passing.

As a counter-argument (pro Social Gospel) Paul's words in depicting the apostolic charge can be raised: "For we are fellow workers of God" (1 Cor. 3:9). Even to this day God calls people as his fellow workers.

Consequently it seems as if the human element in the realization of the kingdom should be acknowledged. We are, after all, "labourers together with God" (KJV). But before we claim too much, let us realise that fellow workers are simply gifted, obedient servants used by God. They have no inherent, autonomous standing, no character indelebilis. Even worse, fellow workers are not indispensable. If they become disobedient God replaces them by others (cf. Van der Walt, 1962:318, with reference to Matt. 22:1-14; Mark 12:9: Luke 19:40).

The idea that the kingdom is in some or other way ours and that we could promote its coming by means of our ethical or political actions reveals a dangerous misreading of Scripture. The menace of political 
theology to the church was clearly stated by Edward Norman in his 1978 Reith Lectures, saying inter alia the following:

In the largest perspective, I shall see the politicisation of Christianity as a symptom of its decay as an authentic religion. It is losing sight of its own rootedness in a spiritual tradition; its mind is progressively secularised; its expectations are prompted by worldly changes; and its moral idealism forfeited transcendence. The prospects are not happy ones.

Thus it remains God's kingdom.

It may be that the consummation of the kingdom will come because of human "scientific" tools, like the atom bomb. Even if man could contribute towards the coming of the kingdom it would be a contribution, not towards the betterment of society, but towards its destruction. It would be a negative contribution, a move in the wrong direction, which falls outside the aims of pragmatism and humanism.

\subsection{The coming kingdom}

\subsubsection{Coming mysteriously}

The kingdom has come and is coming. This mystery of "already" and "not yet" is well known in Reformed theology (cf. Ridderbos, 1972:68; Van der Walt, 1962:34-87). It would be a futile exercise to recapitulate it here. Just note that the kingdom is potent like a mustard seed, yet imperceptible in its operation like yeast. It is visible in the teaching and miracles of Jesus, yet hidden from empirical view (Mark 1:13), for Christ the king appears sub contrario as the suffering Servant (Is. 53), disclaimed as prophet (Matt. 26:67-68) and as king (Matt. 27:27-30). Yet He was finally justified by the signs of nature (darkness over the whole earth, earthquakes) and by the Father, who resurrected him.

\subsubsection{Coming in God's way and in his time}

We pray that God's kingdom may come. It is a call on God to let his kingdom come. He is the sovereign ruler who has determined in his council the means and the manner, the way and the time through which and by which his kingdom will come. In our weak human capacity we have neither the power nor the authority to let his kingdom come. Every pretence that we can manipulate his council is excluded. We can only receive the kingdom as a gift, enter into it like children.

To what extent the coming of the kingdom is totally in God's hands is perhaps nowhere better expressed than in the parable of the marriage feast (Matt. 22:2-10; Luke 14:16-24). The marriage feast (a standing 
expression of the eschatological joy) is prepared. The host sends his servants to inform the invited guests (Israel) that the feast is ready. They, however, make their excuses and refuse to come. Then the host does a most unheard of thing: he sends his servants into the streets to invite all they encounter - the poor and the maimed and the blind. They even have to go out to the highways and hedges, and compel people to come in, that my house may be filled (Luke 14:23). Apart from the universal character of the kingdom revealed here, the point is that the marriage feast will take place in spite of the refusal of those originally invited. God's plan of salvation will be fulfilled in spite of the obstinacy of the Jews (Ps. 33:11; cf. Ridderbos, 1972:180-181).

It was an essential conviction of the Pharisees that, by admonishing and forcing the people to obey the law, they could bring about the coming of the kingdom. As we have seen above, Ritschl, the Social Gospel movement, and liberation theology took up this notion. It is a matter of concern that this erroneous notion is surfacing in Reformed theology. A few months ago I heard a reformed minister calling his congregation "builders of the kingdom" and concluding his sermon by calling upon them to roll up their sleeves and start working for the kingdom awaits our action.

The menace of this notion to the church was underlined by Eßer, saying (1998:77):

Viel ist in unseren Tagen wieder zu hören vom Aufrichten des Reiches Gottes oder seiner zeichenhaften Verwirklichung. Wer das in der Geschichte jeweils versuchte, hat allemal im Endergebnis schreckliche Totalitarismen aufgerichtet und ist in Käfigen gelandet (Münster 1534/35). Wir sollten uns auch in ökumenischen Resolutionen jene protzige Sprache versagen, die vorgibt, Zeichen des Reiches Gottes aufrichten zu können. Gott bringt Sein Reich in Seiner Freiheit, wann und wo es inm gefällt.

\subsubsection{Coming in history}

Since the coming of the Son of man the kingdom has drawn near and is coming. To say that it is coming in history seems to be superfluous. Yet it is necessary to stress, firstly, its coming in history though not automatically. This means that the kingdom is not subject to the supposedly "immutable" laws of history as "discovered" and propagated by all forms of historical thought.

It is necessary, secondly, to stress that the kingdom is truly coming in history. This means that time cannot be "frozen" in the hic et nunc of the existential moment, and the temporal aspect of "becoming full", and of 
"fulfilment" cannot be dissolved into a qualitative higher dimension whatever it may mean.

\subsubsection{Coming "according to the Scriptures"}

The frequent New Testament expression "according to the Scriptures" (e.g. Matt. 21:42; 22:29; 26:54 and 56; Luke 24:24 f.f.; Acts 1:16; I Cor. 15:3-4) refers to the past. Even the very first promise of God in the remotest past intimates the coming of a Conqueror from the woman's seed, someone who would bruise the head of the serpent's seed. This promise, however, is founded upon an immediate divine act: I will put enmity between you (i.e. the serpent) and the woman (Gen. 3:15). God, as it were, overturned the collusion between woman and serpent. Its result was the victory of the woman's seed - the tetelestai of Golgotha (John 19:30) and the empty tomb (Luke 24:5).

Seen from the New Testament perspective of Christ's victory, "according to the Scriptures" is a reference to the prophetic word, a sure shadow from ages past, a sketch (adumbratio) delineating his life and death, his words and deeds, his obedience and passion (e.g. Ps. 22; cf. Parker, 1982:142-146).

Christ's life, however, did not end in death. Scripture proclaims his conquest of death (Is. 53:12; Ps. 16:10-11, quoted in Acts 2:27-28 and Acts 13:35). Thus $\mathrm{He}$ was raised according to the Scriptures $(1 \mathrm{Cor}$. 15:4) and was therewith designated as Son of God in power (Rom. 1:4).

What was formerly written in Scripture about him was expressly stated by Jesus himself, for instance after Peter had confessed him to be the Christ: From that time Jesus began to show his disciples that he must go to Jerusalem and suffer many things ... and be killed, and on the third day be raised (Matt. 16:21).

We are presented here with what is called the "telescopic" view of Scripture: the fulfilment of a prophecy becomes in its turn a prophecy of things yet to come. Christ's coming, for example, was the fulfilment of Old Testament prophecy. In his turn Jesus spoke of his coming in glory at the end of time (Matt. 24). In this respect we are touching upon the mystery of the kingdom again.

Promise and fulfilment, interwoven in prophecy, and clearly portrayed by biblical typology, lends to the Christian faith its solid foundation. 


\section{The guidelines}

The time confronting us is the time we have to confront with the gospel of the kingdom. It is still the time of the coming rule - whatever names the Western world is giving it: modernism or globalism or what have you.

To live in our time responsibly necessitates a knowledge of our time, a knowledge of ourselves and a knowledge of the immovable nature of prophecy.

\subsection{Gauging our time}

Post-words are coming and going, like post-Christian and postindustrial. The present vogue is to describe our culture as postmodern. This qualification is, of course, only applicable to Western civilisation, embracing a minority of the earth's inhabitants. Yet, postmodernism with its concomitant globalism and multiculturalism has immense propagandistic value and is being used as such, particularly by the United Nations. Its effect is even felt in South Africa.

On the one hand we should therefore be wakeful against postmodernism and not underrate its influence. Postmodernism harbours in its bosom some elements that are particularly obnoxious to the Christian faith, inter alia the mystical pantheism of the New Age movement, and the cultural and religious relativism which is advocated with persistent fervour. While some hail the advent of postmodernism as a chance to promote Christianity we should see its true figure behind the mask - an adversary of Christianity, for the absolute truth of the Gospel is incompatible with any form of religious relativism. Besides, postmodernism rejects (by majority consent) all "grand narratives", while the revelation of the coming of the kingdom is the "grand narrative" per excellence.

On the other hand we should not fear postmodernism. Looking objectively at this popular label and at our situation we make only two observations.

- There is no general accepted definition of postmodernism, for its definition is determined by the various views of what modernism means and what the prefix post means. A philosopher friend of mine has suggested that, because of its very relativism, a standard definition of postmodernism is impossible. However, if words do not have a generally accepted connotation any more, communication becomes impossible. Besides, much of what is dished up as postmodernism is really part and parcel of modernism. Alex Callinicos (1991:12) gives two quotations to illustrate this point: (1) "In the multidimensional and slippery space of Postmodernism anything goes 
with anything ... and meaning becomes detachable like keys on a key ring". (2) "The nature of our epoch is multiplicity and indeterminacy. It can only rest on das Gleitende, and is aware that what other generations believed to be firm is in fact das Gleitende". These quite similar statements about our time stem in fact from two different dates. The first comes from a talk by the art critic Suzy Gablik given in los Angeles in 1987; the second from the poet Hugo von Hofmannsthal in 1905. Examples of this kind of illegal appropriation of modernist motifs by postmodernists can easily be multiplied. Contemporary art even portrays a retrogression behind modernism to the fundamentals of the Romanticism of the 19th century. The case in point is Lewell Liebermann's "tonal" second symphony performed in New York a few months ago (Teachout, 2000:64). By going back to tonal music he skips the whole 20th century with its atonal music. The picture of postmodernism is, to say the least, complex and undefined. These remarks are enough to warn us not to take postmodernism too seriously.

- The antique global village of Hellenism with its multiculturalism, tolerance, relativism, and epistomological scepticism was the legacy of Alexander the Great. By conquering the world he expanded the influence of Greek culture, but simultaneously dissolved its impact, and when the rose of Greek culture started to wilt the sceptics entered the scene. Or perhaps the sceptics caused the wilting of the rose. However it may be, our modern global village, apart from its electronic gadgets, differs not that much from the antique one. On the contrary, their basic characteristics are the same. Once again (by means of the first quotations) two additional quotations are used to illustrate the point. (1) "A thing has as many characteristics as there are people perceiving it". (2) "Consensus is a horizon that is never reached". Both statements tend toward a plurality of viewpoints, a lack of consensus. The first stems from Protagoras (480-410 B.C.), the father of the Greek sophists (cf. Stumpf, 1975:43) while the second is from Lyotard (1984:61). Now it is noteworthy that it was precisely in the antique global village that Christianity took root. This fact gives us courage for our task.

\subsection{Looking at ourselves}

To know God implies to know ourselves, our place, our sinfulness, our limitations. This knowledge can only lead us to humbly proclaim the coming of the kingdom, and to pray for its coming. If we have the pretence to do more, hoping like the Pharisees to bring about the coming of the kingdom, we become disloyal, lapse into humanism, and rob God of his pre-eminence. 
We can only pray when we embrace God's promises and subject ourselves willingly to his rule. Without this obedience to the veracity of the prophetic word (2 Pet. 1:19), our proclamation of the coming kingdom turns into unconvincing loquacity. To render the prophetic word disputable - either directly or indirectly - is to deny the kingship of Christ and to refuse the gift of the kingdom.

\subsection{Looking at the future}

The future belongs to God's kingdom for the kingdom is coming as surely as it has come in "the historical Jesus"'. Therefore we have no need of an ahistorical, "kerugmatic Christ". Instead, we have his word, his promise to return; behind us stands his resurrection as the pledge of the first-born among many brethern (Rom. 8:29). The first fruits of the Spirit cause us to sigh together with the cosmos in expectation of the final revelation of the kingdom. The future belongs to his kingdom for from him and through him and to him are all things. To him be glory for ever (Rom. 11:36).

\section{Bibliography}

CALLINICOS, Alex. 1991. Against postmodernism. A marxist critique. Repr. New York : St. Martin's Press.

CALVIN, J. 1964. Institutes of the Christian religion. Vol. 2. Transl. by H. Beveridge. Grand Rapids, Mich. : Eerdmans.

CHOPP, Rebecca S. 1998. From patriarchy into freedom: A conversation between American feminist theology and French feminism. (In Ward, G., ed. The Postmodern God. Repr. Oxford : Blackwell. p. 235-248.)

DOUGLAS, J.D., ELWELL, W.A., TOON, P. 1989. The concise dictionary of the Christian tradition. Grand Rapids, Mich. : Zondervan.

EßER, H.H. 1998. "Mitarbeiter des Zeitgeistes?" Oder Komplimentarität von spirituellen Werten und gesellschaftlicher Verantwortung? (In Bajohr-Mau, K., Jabotey, I.E. \& Süttman, H., eds. Vom Zentrum des Glaubens. Festschrift für Dietrich Braun. Rheinfelden : Schäuble Verlag. p. 67-78.)

GROSHEIDE, F.W. 1953. De openbaring God's in het Nieuwe Testament. Kampen : Kok.

KJV = King James Version. All quotations from Revised Standard Version unless otherwise mentioned.

LYOTARD, J-F. 1984. The postmodern condition. A report on knowledge. Transl. from the French by G. Bennington and B. Massumi. Manchester : Manchester University Press. (Theory and History of Literature. Vol. 10.)

NAUTA, D. 1961. Social Gospel. (In Christelijke Encyclopedie, 6:197.)

NORMAN, E. 1978. The political Christ. The Listener, Nov. 2. (BBC Reith Lectures.)

PARKER, T.H.L. 1982. The shadow and the scetch. (In Calvinus Reformator. Potchefstroom : IRS. p.142-146.)

POSTMA, F. 1914. De numine divino quid senserit Vergilius. Amstelodami : Van Bottenburg.

RIDDERBOS, H. 1972. De komst van het Koninkrijk. 2nd impr. Kampen : Kok.

TEACHOUT, Terry. 2000. Back to the future. Time, 155(9):64, March 6. 
STUMPF, S.E. 1975. Socrates to Sartre: A history of philosophy. 2nd ed. New York: McGraw-Hill.

VAN DER WALT, T. 1962. Die koninkryk van God - naby! (D.Th. thesis.) Kampen : Kok.

VAN NIFTRIK, G.C. 1966. De vooruitgang der mensheid. Nijkerk : Callenbach.

WARD, G. 1998. Introduction. (In Ward, G., ed. The Postmodern God. Oxford : Blackwell. p. xv-xlvii.)

\section{Key concepts:}

kingdom of God

Lord's prayer; second petition

\section{Kernbegrippe:}

koninkryk van God

Onse Vader (gebed): tweede bede 
